\title{
Youth, Participation, Leisure and Citizenship
}

\author{
Lisbeth Lindström*
}

Luleå University of Technology, Department of Education, Universitetsområdet Porsön, 97187 Luleå, Sweden

\begin{abstract}
The purpose with this article is to describe, explore, and discuss texts that ten Swedish local councils present on their homepages from the perspective of leisure, influence and citizenship for youths. Content analysis is used as a method in order to understand the content and structure of texts such as political aims, strategical plans and budgets. The result of the empirical study shows that the picture of youth citizenship is neither uniform nor coherent, but rather complicated and contradictory. On the one hand, the image of young people is that they are presented as individuals who are creative, interested in and willing to take responsibility for matters which concern them. The image of youth is that they need to practice democracy in particular established structures. Young people are seen as individuals who need places to hang around, meet with their friends and have free access to activities such as listening to music, playing games or using the Internet. On the other hand the idea that the young generation needs protection and tutoring, to be watched over, controlled and sometimes guarded by social authorities is also expressed in the texts.
\end{abstract}

Keywords: Influence, citizenship, youth, leisure, democracy.

\section{INTRODUCTION}

The purpose with this article is firstly to describe, explore, and discuss texts that ten Swedish local councils present on their homepages from the perspective of leisure, influence and citizenship for youths. Secondly, I will also explore the role leisure plays, or alternatively might play, in the development of democratic citizenship. Harris, Wyn and Younes [1] claim that songs, dances and gigs are often used as explicit tools for the public articulation of political concerns such as equality and human rights. Other music cultures, songs and dance events have also been analysed as places where young people participate in the creation of politics, as well as in leisure communities with their peers.

The questions that originate from the stated aim are what kind of influence and citizenship will be represented through the local councils' goal and steering documents for young people and their leisure time? What kind of influence and citizenship will be represented through the way the local councils organize, manage and support the leisure sector and what kind of influence and citizenship will be represented through the supply of leisure activities for young people that are presented on the local councils' homepages?, finally, what kind of influence and citizenship do young people visiting meeting places for youth in the local councils experience?

In the first section I present my insights about the theories and perspectives of young people's influence, democracy and citizenship.

In the second section I show how and why some researchers argue that we can see a decline in formal democracy in the entire western world.

In the third section I present the framework of the empirical study.

*Address correspondence to this author at the Luleå University of technology, Department of Education, Universitetsområdet Porsön, 97187 Luleå, Sweden; Tel: +46920491148; E-mail: Lisbeth.Lindstrom@ltu.se
In the fourth section I present a picture of youth, citizenship and leisure as they are presented on the local councils' homepages. This section is supposed to give an answer to the present intended questions concerning the kind of influence and citizenship that will be represented through local council's goal and steering documents, from the way they organize, manage and support the leisure sector, through the supply of leisure activities presented. Finally, I will examine young citizen's experiences of influence and citizenship.

In the concluding section I highlight those dimensions of influence and citizenship that have been visible, such as young people's need to practice democracy and the special structures which have been established to enable this to occur and to provide channels for dialogue with the authorities.

\section{THEORIES AND PERSPECTIVES OF YOUNG PEOPLE'S INFLUENCE AND CITIZENSHIP}

A citizen may be described as a member of a political community or a state, who has certain legal, social and moral rights, duties and responsibilities. Citizenship is a political concept with a variety of rights and responsibilities in a given political community. These rights and responsibilities change over time as the result of social struggle, economic change and shifts in governing ideology [2].

Hemingway [3] is interested in the role leisure plays, or alternatively might play, in the development of democratic citizenship. He implies that there is a move from representative to participatory forms of democracy, the demands on leisure increase accordingly. Further, he states that the citizenship required by a representative democracy can be labelled "weak citizenship" and citizenship required by a participatory democracy a "strong citizenship". Hemingway [3] argues that if leisure is to contribute to the formation of a social capital necessary for strong citizenship, it must 
include the attributes of representative democracy. Attributes such as participation, open communication, autonomy, trust, cooperation and development are necessary for a well functioning participatory democracy. He means that the forms, content, and distribution of leisure activities represent a major potential factor in the development of democratic social capital and thus in the stability of democratic society. Autonomous forms of social activity such as youth clubs in which individuals are able to enhance existing capacities and develop new capacities built on democratic norms can be a breeding ground for a participatory democracy.

Peterson, Hermansson, Micheletti, Teorell and Westholm [4] discuss the meaning of citizenship. They talk about an inner core whereas the idea of a citizenship is built on people's equal value. All citizens must be able to enjoy several common rights and have also some obligations towards the society and to other citizens. Peterson et al., [4] argues that young children and youth make their citizenship different from that of most adults since they are dependent upon adults to be able to claim and exercise their citizenship. The youth are a social construction and a special category of people with different civil rights at different ages. Citizenship for the young is like a transitional stage between childhood and adulthood. James and Prout [5] argue that the public debate about children's and parents' responsibilities is the question about what constitutes childhood. Furthermore, that different public discourses compete to define childhood and its relationship to adulthood and parenthood. Such and Walker argue that definitions of responsibility have been constituted and contested almost exclusively from adult perspectives [6]. On the one hand, parents are assumed to take responsibility for children's well-being; on the other young people are blamed for anti-social behaviour.

Within the new sociology of childhood, the child is seen as a social actor. James, Jenks and Prout [7] claim being a child is not static, it populates history. They even talk about a new paradigm for the study of childhood that is emerging. Furthermore, they claim that the child is active in its own right as an agent in its own construction, similarly to any adult, in the sense of an agency that concerns the initiation of action by choice. James et al., [5] states that children must be seen as actively involved in the construction of their own social lives, the lives of those around them and of the societies in which they live.

Such et al., [6] argue that New Labour have frequently used the concepts of rights and responsibilities in its discussion of the duties of parents and the anti-social behaviour of children and young people without defining what these rights and responsibilities constitute. They mean that the concept of responsibility emerges as a key variable in the definition of modern childhood and generational differences. On the one hand, children are constructed as being free from responsibilities of the adult world, on another hand, modern trends towards individualisation emphasise participation [6]. Bennett [8] argues that our recent generations have entered a time of post-material politics. Young citizens participate by other means through "self-actualizing" or "self reflexive" involvements in personally meaningful causes guided by their own lifestyles and shifting social networks.

In considering the society to come, Arnot [9] questions what sort of citizen will be needed in the future and how youths should best be prepared for the social changes that will occur. Youth cultural research has found that young people today employ the language of individualizing, the concept of freedom and choice, to justify their life styles and decisions [9]. In the same way, Beck and Beck-Gernsheim [10] describe what they call "Freedoms Children". By that they mean children who have been brought up, unlike their parents, to become choosers, or consumers of what life has to offer. This new culture is described as a self-culture and it is tightly connected to leisure. Arnot ague central to this selfculture is the process of individual reflexivity in which individuals come to see themselves as the centre of their own life-world [9]. This article focuses on the picture of youth and youth citizenship as it appear in political aims, strategically plans, and budgets presented on local councils homepages.

\section{Youth Participation in Formal Democracy}

In all the Western World, youth participation in formal democracy is declining Harris et al., [1]. It is found that young people see a lack of connection between voting and democratic participation with everyday politics. They do not perceive voting as an important component of their daily life. Lack of trust in political leaders is also clearly evident. However it is also seen from other scholars that young people do have political views and participate in alternative political behaviour but they are not well informed about the role of citizens. Harris et al., [1], Bennett [8], Print [11], Osler and Starkey [12], O'Toole [13], Bang [14] argue that the new generations of citizens are simply redefining what they mean by politics, and that scientists should embrace this shift. Bang [15] argues that the scope of the political in late modern society is expanding and is expressed more and more in, and through, people's everyday lives which suggests that the political is now personal. O'Toole, Marsh and Jones [16] research show that young people are very far from being politically apathetic, they were found to be highly articulate about political issues. But a very strong sense among their respondents was that they felt marginalised or excluded from political decision-making or debates. They felt that politics is something that affects them but not something that they can influence. Based on lived experiences of class, gender, ethnicity and age, their research revealed many inequalities.

Helve [17] has investigated value structures among young people in Europe in order to find out their ideological preferences. The categories presented ranged from the ages 16 to 19 . Her study showed that although different value structures can be found among young people, only a few clearly belonged to just one category. The values the youth preferred were in accordance with the situation in which they found themselves. This means that the same young person may choose statements as an individualist in some situations and as a humanist in others. Helve, therefore, claims that it is worth asking what type of citizenship will be suitable for young people with floating values and a variety of subcultures [17]. Hoikkala [18] describes the young people of today who are around thirty years old as the "sandwich generation" (p. 10). The "sandwich generation" extend their youth by travelling, consuming and enjoying themselves. However they get anxious, have feelings of loneliness and 
suffer from psychophysical symptoms. He also talks about the "yo-yo" generation that is constantly drifting between work and unemployment [18]. Investigations in Sweden and other countries have shown that young people are concerned about society and want to influence questions that are important for them Sörbom [19], Sörbom [20], Sörbom [21] and Harris et al., [1]. However, youth are turning away from conventional party politics and instead show involvement in networking, activism, and political consumerism e.g. boycotting certain goods [22]. Smith, Lister, Middleton and Cox [23] even argue that this lack of citizenship among young people is in need of intervention in order to develop their citizenship. Even if young people hold political views, they do not have access to formalised channels such as voting. Neither, have they the ability to influence or to change political decisions [22, 24].

Mossberger, Tolbert and Stansbury [25] state that new communication forms like chat rooms and e-mails represent new modes of information exchange and opinion mobilization. There are new opportunities for shared political information and communication on the Internet. Other scholars [26-28] suggest that the Internet may function as a deliberative public forum, something which can strengthen democracy [25]. There is a fear however, that information technology will promote further inequality in democratic participation and widen the gap between those who participate and those who do not [29-31]. On the other hand, young people as groups seem to acknowledge digital democracy [25]. The Internet can be a site for construction of new forms of connection to society and the development of citizenship.

Gallagher and Hafner [32] state that by using modern technology it would be possible to make citizens aware of governmental activities which bring them into the decisionmaking process and, in addition, also bring the government closer to the people. Gallagher et al., [32] further state that since such a large amount of the youths' time is invested in online social networking, they might be more likely to exercise their political authority if they got the opportunity to vote online. This can be called e-democracy, which is a relatively new concept that involves using technologies such as the Internet and cellular phones to bring the government closer to the people.

\section{The Framework of the Empirical Study}

Sweden is a parliamentary democracy, which means that it is ruled by a political majority and general elections are held every four years. The Swedish Parliament, (riksdag), which has 349 members, is the supreme political decisionmaking body in Sweden. Sweden has three levels of government - national, regional and local. In addition there is also a fourth level, the European level. Sweden's fundamental laws, which make up the Constitution, hold an exceptional position in its legislation and cannot be amended as easily as other laws. The fundamental laws cover the form of government and democracy, freedom of expression, freedom of the press and the order of succession to the throne.

This article describes, explores and discusses official texts visible on homepages from ten Swedish local councils. The article focuses on the picture of youth presented in the material found in texts and documents such as political aims, strategically plans, and budgets.

The choice of local councils for the research was done with the intention of geographically and social culturally representing local councils from the whole of Sweden. There are 290 local councils in Sweden. Local councils were also selected according to the amount of inhabitants, such as small, middle and larger local councils. The selection was made together with representatives from the state agency (The Swedish national board for youth affairs) responsible for implementing Swedish youth and recreation policies. The chosen councils are not intended to be a representative selection of the total amount of Swedish councils. They were divided into three categories, a metropolitan municipality with a population of over 200,000 inhabitants, larger cities, suburban and commuter councils with less than 200,000 inhabitants and sparsely populated councils with less than 20,000 inhabitants. The age distribution was also considered when selecting local councils, and whether they had a lot of young citizens or a more elderly population. In the selection of local councils, I had also attempted to keep in mind patterns in the research material. I was for example, interested to know whether there were some similarities and differences between local councils in the north of Sweden or local councils situated close to Stockholm and Gothenburg. The selected local councils were Boden, Sundsvall, Munkfors, Örebro, Uppsala, Linköping, Haninge, Lund, Motala and Gothenburg 'City Centre. These councils were even chosen because they had homepages which gave a fairly good view of their activities and polices.

Municipality leisure activities are mostly governed by a culture and leisure board and its decisions are implemented by civil servants at the local administration office. These boards have the responsibility to cater for all citizens when it comes to leisure and culture. Activities for young people are just one part of their work.

The official texts on the ten local councils' homepages can be written by civil servants at the leisure administration or at the leisure board. Texts can also be written by youth leaders who work at youth clubs or other meeting places. They can be written alone by the youth leaders or by the leaders together with the youths. The analyzed texts mirror perspectives of three levels, the societal, the local and the institutional.

The way the leisure sector is presented on the homepages of the local councils may indicate both the values a council put on leisure activities and the ideas about how to communicate with citizens of different ages. How the leisure sector is organized and managed is, of course, also a function of size and the amount of inhabitants in the municipality.

The societal level in research covers national and international policy, conventions and laws, which are of importance to the leisure sector. These documents represent the overall ideology which should permeate the local activities. The question is if this is seen in the texts on the local councils' homepages.

At the local level the political documents were scrutinized, which emanate from the boards decisions. The way this is organised and managed in the different councils were studied from the perspective of what intentions are 
expressed in the texts and how these harmonize with organisation and management.

The third level represents the actors, who are involved in implementing the activities of the leisure sector and the presumed individuals and groups, who gain benefit from the activities.

\section{Method and the Line of Action}

The line of action for the study of the text is as follows. After the local councils were chosen the process started to systematically search for information on the Internet from each of the local council's homepages. It was a rather long process to find all material of interest and to follow all links that led to information relevant for the research questions as the structures were different. It was also necessary to go back to the web pages many times to be sure that all material relevant for the research questions was found. The amount of pages differed between the local councils. In total about a thousand pages were found and printed out. All documents found from the search on the Internet involving leisure with a special focus on open leisure activities are included in the material. In appendix, Chart 1 a list of all documents and pages used in this article are presented. The documents with the name and web addresses and dates are presented beneath each local council.

To search for information on the Internet is a complicated process. The local councils have homepages and pages reflecting different structures. A reader of the pages does not encounter a unified structure and pattern. In some of the local councils it was necessary to search many links on different levels to find relevant information. The information was also spread out on many sub pages such as from the boards, the leisure administrations, youth clubs' own homepages and youth divisions' own homepages. Documents and information have also been visible directly on the local councils' homepages as written texts not presented under special links.

From the beginning the focus was solely on texts about leisure for young people. However, in some of the documents from the smaller councils, the text only discussed leisure in general and very little was said about leisure for young citizens. This means that documents that more generally talked about leisure are also analyzed. This was expressed in texts like leisure facilities for "all" citizens or leisure activities organized and offered to "all". In the study it was of interest to know what was explicitly stated in the texts of the documents. This means that the study focuses on the way the texts are written, the content and in what context the texts are presented.

The authors of these texts, who are civil servants in most cases, have created a contextual coherence through naming different phenomenon and by using a specific discourse. That means that the leisure discourse is used as a general idea that language is structured according to different patterns that peoples' utterances follow when they take part in different domains of social life. Through these discourses, which delegitimizes or limit certain things while it includes others, a reality is constructed [33]. In the study it was also of interest to unveil what is expressed in the text and discern the contextual reality [34]. For example it was of interest to find out about issues such as accessibility to leisure, the importance of a balanced budget and expressed goals and aims. Politicians expressed interest in supporting the leisure sector and the way this emerged in the documents was also analysed. This included premises about citizens' welfare, needs and expectations and their possibilities to influence these factors. Within this contextual reality about leisure and leisure's contribution to young people's lives, young people's citizenship is analyzed.

Textual analysis is a way to practice research in social science. To analyze a text means to review the structure of the text and scrutinize the content, which can be done through content analysis. Textual statements and perspectives are often written in an ideological framework. Sometimes a text can consist of basic facts, sometimes of complicated interpretations and conclusions of linguistically constructed pictures of actuality or the state of something that actually exists objectively. For example a basic fact can be the number of visitors at a youth club. A statement of something that exists can be the presence of drugs at a youth club. There may even be complicated interpretations concerning the reason for referring young people with certain disabilities to a special youth club.

There can be different voices and positions from which those who are talking in the text express themselves. The ways in which the receiver is addressed may also differ, for example whether texts are addressed to grownups or to young people. Sometimes a text contains a counter-reaction or counter voices. The text can be homogeneous or heterogeneous, sometimes open and consistent in its attitude or sometimes masked under a veil of an objectified subject. In this study this is interpreted in the sense that a subjective value is understood as an objective truth. In an explanation of what textual analysis is, McKee [35] responds that when we perform textual analysis on a text, we make an educated guess at some of the most likely interpretations that might be made of that text [35]. He means that texts are interpreted in order to try to obtain a sense of the ways in which people, in particular cultures at particular times, make sense of the world around them [35]. Bruhn Jensen [36] view is that it is only through language that sense can be made of the world.

Content analysis can be done both qualitatively and quantitatively. There are different kinds of content analysis. One of the key features of qualitative content analysis is that the context is central to the interpretation and analysis of the material [37]. This is the way content analysis is used in this study. Further, content analysis is used because of the interest in how the text describes certain phenomena i.e. what standpoints authorities take and what arguments they present. Furthermore, it is interesting to discover what leisure activities are promoted and how the texts mirror values and norms. Subsequently, it is of interest to examine how the texts talk about concepts such as equality, sustainability, democracy and accessibility, how and in which context, these words are used.

With qualitative content analysis it is possible to study interpersonal aspects that have to do with the interaction between citizens. It can for example, include how different authorities talk to their citizens or how producers of leisure at youth clubs talk to young people. It is argued that the manual content analysis makes it possible to do more 
advanced assessments, estimations and interpretations. With the use of the content analysis it is also possible to have a greater overview of an often relatively large amount of research material as is the case in this study.

In this study, qualitative content analysis is used as method, starting with a theory and research findings as guidance for initial codes. The object of qualitative content analysis can basically be any kind of protocols of observations or written documents in general. Not only the manifest content of the material is analyzed, but also what can be called latent content as well as formal aspects of the material. The word latent is interpreted as something that is veiled and not directly visible. Kohlbacher [37] argues that the strength of quality content analysis is that it is strictly controlled methodologically and that the material is analyzed step by step.

The empirical study proceeded through different steps [38]. Firstly each document was printed out. The next step was to read through all of the material several times to find texts that had to do with young people and their leisure time and make notes in relation to the notion of citizenship. Reading the documents several times gave a feeling of the totality of what the documents express. Sometimes it was necessary to go through and then return to the documents for the selected local councils. During that process statements and phrases containing information relevant for the study have influenced the questions being selected.

Notes were made on the documents about expressed citizenship, committed resources, strategies and activities, and what values were mirrored in the text. Through the whole process the aim of the research and the research questions were in mind and the theoretical perspectives were used as a screen for the text. One step was to make a reduction of the selected material, by listing the documents and their main contents connected to the theory and to the research questions. From that a coding agenda was made. The units of meaning such as sentences, words and phrases were grouped in different fields: forms of steering, type of goals, different documents, management and operation methods, forms of participation and facilities offered and supported. These fields were helpful as a first step in sorting out the huge material as they mirror the central content of the texts in relation to what kind of citizenship is expressed. Through these the material was structured and summaries were made. This was the first constructed tool and was further used in the analysis of the empirical material.

The research method aims to be observant of special words and statements, which seem to be relevant for the research questions, how they occur and in what order they occur. In stating this, it has not been of interest to count the amount of times they occur but rather whether words such as influence and democracy occur at all. Of interest has been how they occur and how they are discussed in documents and what kind of citizenship they represent. After reading through the material several times certain traits emerged and the coding agenda had to be revised. For example, citizens' health and citizens 'possibilities of having access to leisure facilities and outdoor life activities were mentioned in some texts. Disabled citizens and citizens in the margins were often mentioned too. The priorities made and values expressed in the text have also been of interest. Sometimes surrounding texts have been included in the interests of visible coherence. This occurs for example, when questions about leisure time and school are intertwined because of a common board responsible for questions concerning school and leisure. This can for example be an education and leisure board. This implies that documents that are written about children and young people's leisure time when they in some cases are connected to school questions are also included in the study. Some local councils such as Uppsala have a political board and an administrative division that do not handle young people's leisure time and leisure at school time as separate questions. For example, youths' leisure time can be mentioned together with questions relating to social services and which have a connection to the law of service and support (LSS), in contact with the police or about facilities for leisure situated close to school buildings.

The next step was to construct final categories, which could be systematically used to scrutinize the different dimensions of importance for the understanding of the notion of citizenship for young people in all the texts. These categories were democracy, influence, participation, responsibility, self confidence, sustainability, accessibility, gender, ethnicity, quality and integration. I started to list what the different texts expressed and what intentions were formulated. I further analyzed what kind of diction the different texts had, in what context the texts were written and what kinds of attitudes were expressed. Lastly I noted whether the reader of the text was invited to any kind of interaction. A strategy I used was to identify the senders of the texts as civil servants or youth leaders. That means that I am also relating the text to the context of how it is written and how leisure is connected to the civic society more generally; for example, for the development of social capital, solidarity and trust. This can be seen in how authorities write about cooperation and collaboration with the civic society and their forms of management and organization of leisure.

To conclude, I searched for the ways the documents wrote about young people's leisure and what needs and expectations they expressed about the young. I searched for the picture of citizenship that could be drawn from the ways the local councils formulated texts in goals and steering documents. I also searched for activities provided and visible strategies aimed at the development of young people's citizenship, and what values they mirrored.

\section{RESULTS - YOUTH, INFLUENCE, LEISURE AND CITIZENSHIP}

In this section, the empirical part, I examine the situation of youth influence, leisure, and citizenship as presented on the local councils' homepages. Firstly this part is supposed to answer the questions concerning what kinds of influence and citizenship are represented through local council's goal and steering documents; this is presented within the subtitles Leisure management, The Swedish state and four perspectives and Who is the producer of the text? Secondly the questions concerning how local councils organize, mange and support the leisure sector; this is presented within the subtitles, What issues are mostly found in the documents?, Establishing places for safe and meaningful leisure, The images of youth and the supply of leisure and finally, A 
place just to hang around. The questions concerning local councils supply of leisure activities is presented within the subtitle Funds.

\section{Leisure Management}

Leisure management is not mandatory for the Swedish local councils. However, the councils have a responsibility to cater for the leisure of their citizens, an obligation which is stated in laws and rules on both a national and international level, for example the System of Governance, Law of service and support (LSS) and the UNs Children's Convention. Direct references to international conventions are found only in a few of the documented aims; for example in Lund it is stated that UNs Declaration about Human Rights and the Children's Convention are fundamental documents and shall be kept in mind for all activities in open leisure activities in [39].

One example of the laws that the Swedish councils have to consider is the Planning and Building law. The law states (chapter 2, §5) that local councils should arrange green areas for recreation, which should be accessible to people with mobility and orientation disabilities. Chapter 5, $\S 3$ includes regulations about facilities for athletics, sports and open air swimming. Another law that is important is the Law of Service and Support for People with disabilities (LSS, § 15), [40], SFS (1987:10) [41] and SFS (1993:387) [42] which states that disabled people are entitled to leisure activities. The demands of this law are very much present when the texts in the document talk about people with handicaps. The activities in youth leisure centres are also indirectly affected by the law of social services agencies $1 \S$, SFS (1987:10) it is possible to find the aims for democracy, equality and involvement in social life [41].

\section{Who is the Producer of the Text?}

The way the texts are written on the different homepages reveals differences which are dependent on who is the producer of the text. The way the young citizens are addressed by administration officers, youth leaders and voluntary leaders varies and different pictures are given of how leisure is constituted. The question is what these differences mean and what values and notions they mirror.

The first contact with the leisure area in the local council is often a page which is created to provide information about leisure and culture either for all citizens or just for the youths. These pages have attempt a layout of pictures and text, which intend to be interesting and inviting. Often there are pictures of young people actively doing things. There are big differences in the way the documents are written, depending on who is the producer and also what type of document it is. The general pages addressed to young people are often flashy and colourful, while the pages of the administration offices are rather formal. Besides, more formal documents linked to the homepages are written in a bureaucratic way, such as annual reports or minutes from meetings. It is the same with information from the administration or plans and budgets from the board.

When the producer is the personnel responsible for the youth clubs there is quite a different form of communication.
The youth clubs seem to have an amount of autonomy, which some of the clubs' own pages bear witness to through comments like "we can", "we have" and "we offer" in the text. This can be seen in the local councils in $[43,44]$.

This can also be illustrated by the 14 youth clubs in Örebro. Each one has a homepage of its own linked to the homepage of the council. Five of the youth clubs only give short information concerning opening times and who is in charge. About five are more inviting, as they present pictures of their activities and invite the reader to interact.

There is also a third category. These youth clubs have pages, which are very rich in information and messages. One example, Brickebacken, presents itself under the heading "Come to our youth club" and decelerates its mission and information about activities and excursions in a colourful way with pictures from an art gallery.

We believe it as important that our young citizens can feel safe and comfortable visiting our facilities. We strive to achieve that our visitors shall take responsibility, and feel that they are a part of and understand that they can influence and make their voice heard. You are welcome with your own suggestions, and we will try to fulfil them [45].

This shows how different authorities talk to their citizens and how the young people at the youth clubs are talked to. In the aims of Brickebacken the youth club is mentioned as a place for communication, where the young person can be with other visitors in a private way.

\section{What Issues are Mostly Found in the Documents?}

As was illustrated in the previous section, there are differences in the way the texts on the homepages are written, but in most cases directly or indirectly expressed norms and values can be found in the documents. The most common values are about democracy, which includes information about dialogue, participation and influence. An overall concern about young people's responsibility and self confidence is also seen in the documents.

The matter of young people's influence and participation seems to be a main issue as texts about this are seen directly or indirectly in all local councils. An ambition is expressed to let young people at least decide about their own activities. In almost every local council, special assemblies through which young people can exert influence are presented on the homepages. They are titled in different ways such as "Forum for the young", "Board of youth", "Youth advisement" etc. but the purpose is the same. These forums are described as a possibility for young people to practice their ability to think critically, to make their voices heard and to have a chance to influence and to be involved.

In a document from the Culture and Leisure board of Haninge local council, an overall concern about young people's involvement, participation, dialogue, influence and involvement is expressed.

The overall aim is to increase young people's engagement through participation, dialogue 
and influence. This can be achieved through development of the youth council and the youth representative assembly but also through developing a forum on the Internet where politicians and youths can meet and develop a democratic dialogue [46].

It is not only the formal representative way that is suggested in the text but also a more open dialogue with the politicians through the Internet. This indicates a wider view of influence and citizenship than the traditional one.

In Uppsala, there are texts which, to an even greater extent, point forwards the elaborated concept of citizenship. The young peoples' need for meeting places as a way to be included in society is recognized. The local council has written a guide for accessibility to culture, leisure and sports in Uppsala which states that leisure time meeting places are created as large social networks, which contribute to increased integration and mediate the fundamental values of the society [47]. What these values are is only implicitly expressed. However, it acknowledges them as an important arena for a democratic society.

In all the councils, the aim of arranging meeting places for young people is expressed. These can be common youth clubs, open houses or youth cafés. These places are said to be non commercial meeting places for young people, which is conscious ideological position. In the investigated councils this is the situation in most cases regardless of the name. In many of the councils, youth clubs have been transformed into different kinds of youth centres like "Multi-activity centres" and "House of youth" run by managers other than the council.

The local council in Uppsala arranges meetings between the politicians and the youths twice a year.

The meeting place. Do not let other people make the talks for you. Did you know that Uppsala local council's politicians must listen to us youths before they make any decisions that concern us? The meeting place is the place where you talk and politicians listen before they make any decisions. The meeting place is arranged twice a year. What we are discussing next time is up to you how you decide to participate [47].

In the document mentioned above which is visible on Uppsala local council's homepage a clear statement is made claiming that the young people themselves decide the agenda. It is also said in the text that the politicians must listen to young people before they make decisions about questions that concern the youths. All the quoted texts express the norms of a representative democracy, in which the citizens should engage in a dialogue with the politicians. Besides, the texts seem to mirror a concern about getting to know the opinions of the young people in the council [47].

The youth assemblies are a way to meet with the young. Another type of channel which helps the politicians to get to know what young people want are special sites on the Internet, which are seen on almost every local councils' homepage.

\section{Establishing Places for Safe and Meaningful Leisure}

Other values and norms that are emphasized by the local councils are the issues of drug prevention and safety. Young people are seen to be in need of support to be able to withstand the temptation of drugs and crime. The city centre of Gothenburg is one example of a local council that is interested in working with strategies for health and to reduce the use of drugs and crime. A Little social welfare office (Lilla socialbyrån) and a unit Social Unit entitled (Sociala enheten) are established that works to ensure that the local council puts into practice laws such as LSS. The text states that:

/ ... through a health fostering strategy the city centre of Gothenburg will prevent insecurity, criminality, drugs and unhealthy living. / ... / To avoid the increased use of drugs and criminality all forces must pull in the same direction. In the City of Gothenburg schools, social services, the field of leisure, parents, police, associations, single citizens and business industry must cooperate to create a safe environment [48].

It is notable that the term "fostering" is used in the document. Although not all councils openly state the aim of preventing crime and drugs, all of them have some organization to implement this. It can be field workers, walking on the streets, special teams to meet young citizens at their meeting places or some civil servants who have a special assignment to be part of the social emergency group. Club leaders, police, human service agencies and other authorities in the local society should work together to curtail any problems that arise.

In Uppsala where the use of drugs is said to be increasing, the authorities make statements about this issue. In the so-called drug political policy one can find the following quotation:

An indulgent and permissive attitude to drugs from our society can have the consequence that the problem of drugs will increase. Even the connection between different drugs such as tobacco - alcohol - drugs, are scientifically improven [47].

In a similar way, the educational board in Motala writes in the aims, directions and results for 2008, that leisure time and leisure activities shall be safe for the visitors in terms of drugs, bullying and other inequalities and also be a physically safe place. The documents further state that to be able to fulfil this aim they need youth leaders or youth workers and talk about their job assignment as follows: "/ ... their mission is to be at places where adults are scarce" [49].

\section{A Place Just to Hang Around}

A strategic document from Sundsvall local council, with the title "Aims from the culture and leisure board 2004 and 2007", states that the youth clubs are first of all for the young people, who are more attracted by open leisure 
activities rather than leisure associations with organized activities. The text states that in the clubs young people can come and go whenever they want during opening hours.

The youth clubs are mostly for groups of youths that prefer leisure activities that are unplanned. Activities aim to give young people's possibilities to just "be" at the youth club without doing any organized activity. The youth club shall be a place where young people can meet with their friends and with adults in an environment where they are able to build up good relations [43].

The message of the text mirrors the idea that the youths at youth clubs are different from other young people and that they only need a place to be at where they can meet with friends.

On Munkfors local council's homepage, the issue of what expectations youths have is evident in the following formulation:

The youth club is a meeting place for young people in Munkfors. Young people come here for a cup of coffee, to watch TV, listen to music, surf on the Internet, perhaps play table tennis and billiards or just to mingle. In the cafeteria you can find coffee, soft drinks, sandwiches, candies and ice cream to buy at a reasonable price [50].

There do not seem to be any demands on the visitors at all. They are just addressed as consumers. Another example of how the users are addressed is found in Boden local council. The information given to the young people is more like a statement:

The house of youth is situated in the old fire station on the road "Strandplan". Here you can meet youth leaders working in the cafe and they also arrange different activities. In the hall divided into two sections you can find among others things a billiard table, ping pong table, facilities for handicraft, music room and dance hall [51].

The activities listed indicate what interests the youth are expected to have. Both these councils are very small and the activities are directed to all young people between the ages of 15-25. That might be the reason why there are no explicit aims and goals.

\section{The Image of Youth and the Access to Leisure}

As I described in the beginning of this article, the assumptions about today's youths is that they are individualistic and see themselves as the centre of their own life world. Young people are supposed to have different life styles, be creative and to be interested in what new information technology can offer them. Furthermore, youth quickly change preferences and express their ideological standpoints through creative work and festivals. This picture can be seen in the local council's documents. In the local councils' documents there are more or less explicit assumptions about the character of young people today.
A way to reach the interest of young people, suggested in some of the documents, is by enabling creative work. This is recognized in some of the bigger councils, where young people are offered access to a recording studio and a theatre scene to produce their own musical or movie. On the homepage in the city centre of Gothenburg, the leisure board strategies of one of the youth clubs are presented in the following way: "Meeths in the middle of the town is starting again. Come and play your own music, work in the art studio, film studio, photo lab, wood working room, edit music and videos, work with ceramics, learn about DJequipment" [48].

The text clearly gives a picture of young people as creative and artistic. In Haninge e.g. the youths are offered to learn about art, painting and photography [46] and in Lund one of the youth cafés has a gallery, where the visitors can exhibit their own work.

Wickmanska is described on the page [39] as a cosy and cheap café were one can take a Café Latte or a cup of tea.

No necessity to buy! You can buy just when you want to. At Wickmanska there is also an "inner place". It is a place where young people can fix (mecka) with a lot of things such as painting pottery, or sewing. Wickmanska are also following the latest news on internet - wi-fi without any cost [39].

One can also read that Wickmanska keeps up with the latest Internet innovations. They have a wireless Internet hotspot.

A notion about what young people want to do also characterizes the provision of other types of facilities for young people. For example Linköping announces "Hangaren Hot Sport Center" on the page where the council's meeting places is presented. The description below shows all the different possibilities that an activity house like this can offer;

Hangaren has something to offer for all regardless of age. Here you have the opportunity to skate with in-lines, skateboard or ride BMX or why not just take a cup of coffee/soda in our café. Besides being a skate hall Hangaren also has a sport hall where young people among other things can jump on a trampoline and participate in dance courses. We also arrange discos in the sport hall on several occasions during autumn- and spring term. All activities in the hall are of course run in a drug and smoke free environment. In Hangaren one can find a climbing wall run by Linköping's climbing associations [44].

The style of the text is inviting and the text enumerates a lot of different activities. It is not just new sport activities that are offered but also disco and dance, which may attract the girls.

A sensitivity to new trends and lifestyles among young citizens is seen in the city regions, in particular the councils 
near to Stockholm, such as Haninge, Uppsala and Linköping. The need for events and festivals as well as activity parks is identified. For example, "Elsas Hus", a culture and media house or the music house "Skylten" in Linköping local council

Still, if the documented activities are aimed at all young people most of the councils address the matter of accessibility and equality when formulating goals. Many of the local councils raise the question in their documents about those citizens for whom accessibility and availability may be problematic. On the local council's home page in Lund [39] it is written in a program for sports activities from 2004, in a report on pedagogies and leisure 2004-2006 and in the aims from the culture- and leisure board from 2006 that the council wants to be an inclusive community with facilities adapted for disabled citizens. It is further stated that inclusion is a concept that accepts different values and takes care of the possibilities that differences give. This is an ideological statement and in line with what the law LSS states.

In some councils, the responsibility to meet the needs of special groups has resulted in certain arrangements. Both in Sundsvall and Uppsala there are separate activities intended for young people who are disabled and in Haninge one of the youth clubs has a special mission to cater for socially disturbed youth. The following is written on the page of one of the youth clubs: "It was possible, thanks to the LSS, to open a special section for children and youth with Aspergers syndrome" [46]. At the same time, texts are written on the page about the ambition to integrate leisure activities for disabled young people in ordinary open leisure activities at the youth clubs. "Disabled young can find integrated activities at several youth clubs and meeting places" [46]. This is a contradiction because in the above quoted document the opposite is suggested. In Haninge, the council has not chosen to be inclusive but instead cater for separate activities for the handicapped.

Another aspect of accessibility is raised in the documents of almost half of the councils, namely gender. In Sundsvall, as an example, the ambitions are expressed in Political program for sports and leisure as follows: "Boys and girls shall be given equal opportunities to actively engage in sports and outdoor life. Today girls often choose other leisure activities than boys, but there shall be equal opportunities" [43].

In Sundsvall, the idea of separate opening hours for girls has been on trial. This is presented on the home page of Young in Sundsvall. "Every Tuesday evening we have groups for girls with themes like ghosts, make-up and gender equality" [52].

\section{Funds}

Another type of strategy that is presented in the documents is financial support, which the youth can apply for when starting different projects. The bigger local councils have funds for young people to use for projects like concerts, events, and adventures which can have positive effects on their citizenship.
This type of money is found in many of the local councils under different names. In Linköping it is named "Youth check account". In Örebro it is called "Young penguin" and in Sundsvall "Young pot". In Linköping e.g., the applicable amount of money is from 500 to 5000 Swedish crowns for each project. Uppsala local council has a total sum of 25000 Swedish crowns to give out. Haninge local council has also a limit of 25000 Swedish crowns, which one single person can apply for. It is not a lot of money but nevertheless it gives the youths a possibility to realize some of their ideas.

Uppsala local council invites young people at the homepage to apply: "At our local council you can apply for an amount of money for different activities for young people" [47]. Linköping local council has stated in their political aims from the culture- and leisure board that the applicants must be between 13-20 years old and form a group of at least two [44]. Sundsvall local council is inviting young people to organise a group of friends to apply for money for arranging concerts, theatre performances or making films [52].

The following example from Örebro local council gives more detailed advice to the young citizens. The information is found on the local council's homepage under the link named "Young money".

Young citizens between 13-24 years can apply for money to organize events for other youths. The events must be free of drugs, religious and political propaganda. They must be performed in Örebro and it is not possible to search for school projects or for sports events [53].

These funds are presented as a way of enhancing democracy and promoting citizenship. It is further stated that whether it will be successful or not depends on the involvement of the young people themselves. It will depend on what the money is used for and how many young people at the youth clubs the funds will attract.

\section{DISCUSSIONS AND CONCLUSIONS}

Citizenship is a central theme in the government's involvement in leisure. During the latest part of the $20^{\text {th }}$ century, the question about young people's citizenship has been actualized in Sweden and Europe. The reasons for this are partly attributable to young people's decreasing interest in political parties and other associations of thought, the occurrence of anarchistic youth revolts, and the spread of fascistic ideas among the young generation.

As I have discussed earlier in this article, leisure, influence and citizenship for young people have a strong connection. This is what I also have found in the documents which I studied. The government looked upon voluntary associations as forums for fostering young people into decent and democratic citizens. The same was found in the local councils, where a special concern was the youths, who did not join voluntary associations. Youth clubs, managed by the local councils and run by educated leaders were organized. Hence young people's citizenship has come in focus. From 
this perspective leisure time is important as young people spend a lot of time in leisure activities. It is a mission for the local councils to both cater for young people's leisure activities and development as citizens.

In the documents, the word democracy was frequently used both as a way for the youths to have influence and as a formal way of deciding on matters of importance. Democracy as formal means was especially seen in connection with the activities of the youth clubs. That the young visitors should be involved in deciding about the activities at the youth club seemed to be evident but it was pronounced that it should be done in a formal way and guided by youth leaders. Many of the activities at the youth clubs and other meeting places can be characterized as, what Hemingway [3] labelled, participatory democracy. Research has found that young people have possibilities to develop themselves, enhance existing capacities and develop new capacities built on democratic norms and finally develop their citizenship.

Another aspect of formal democracy that is of concern for the local councils is representation. To meet representatives of the youth groups in the council, most of them had established different kinds of youth parliaments or youth assemblies. These were also seen as meeting places between young people and the politicians. There are at least two problems with these assemblies. One is the question of whom the members of these assemblies represent as they are handpicked or just randomly asked to take part. The other problem is that the assembly does not have any power to force matters and will easily be neglected by the politicians. This was also something that happened in one of the local council in this research. To meet the first problem, some of the councils have opened channels on the Internet, where the young people in the municipality can chat with mates and authorities and express their opinion in matters of importance to them. Scholars like Norris [26], Hague et al., [27] and Grossman [28] argue that the Internet may function as a deliberative public forum, something that can strengthen democracy. In one of the local councils was a chat established but just handful young citizens had used the possibility during the years.

When addressing democracy, it is mostly the traditional aspects that are mentioned but from a participatory perspective. Looking at what is written about the youth clubs and meeting places for the young, the documents show an adaption to young people's interest and need of individual choices. Comments like "we offer", "you can" your interest" and "your needs" are often addressed to individuals in the documents. This is an example of an ambition from the youth clubs to meet the needs of a generation who have entered a time of post-material politics. Young citizens participate by other means through "self-actualizing" or "self reflexive" involvements in personally meaningful causes guided by their own lifestyles and shifting social networks. The youth clubs in this research seem to have an ambition to fulfil these needs.

The picture of youth influence and citizenship which emerges from the documents is neither uniform nor coherent but complicated and contradictory. The image of youths is at least two sided.

On one hand, young people are seen as individuals who need places to hang around, meet with their friends and have free access to activities such as listening to music, playing games and using the internet for chatting. These are the youths who do not enrol in voluntary leisure associations. On the other hand there are discussions about social problems and the risk of going into drugs and crimes. The idea that the young generation needs to be watched over, controlled and sometimes guarded by social authorities is also expressed in the texts. The picture presented is that young people need protection and tutoring.

Another part of the picture is that the youths need to practice democracy. Special structures are established to enable this and give channels for dialogue with the authorities. Some of these channels, such as different assemblies, are organized in a traditional way as a deputation, while others, on the internet, are informal and open to everyone. The idea seems to be that young people need special democratic channels in order to exercise their citizenship. Open meeting places for youths should be places where the younger generation learn formal democratic procedures and practice democracy with their friends. In addition, there is the question concerning young people's need for education and supervision by adults. Based on research it is possible to be critical of local council's huge ambition and the expectations of the capacity of what leisure activities such as youth clubs can do for young peoples and their development of citizenship. The implication of this study is that it is a complicated mission to learn young people about democracy, letting them take responsibility for concerts and activities and at the same time prevent the use of drugs and young people acting in a criminal fashion.

As young people's citizenship has come in focus in many countries this study is also interesting for an international audience. It is a mission for the local councils to both cater for young people's leisure activities and development as citizens. In addition, many young people of today do not have access to the labour market. From this perspective this study is important as young people spend a lot of time in leisure activities. The study shows that youth clubs and similar meeting places have an ambition to fulfil young people's personally needs.

The conclusions that can be drawn from this research in terms of the theoretical perspectives and, the textual analysis of the documents are that individual young people have opportunities to experience democracy and develop their citizenship through leisure activities offered by local councils. However, the aims and intentions expressed in documents on the local councils' homepages must be fulfilled. They must be explicit expressed, systematically evaluated and guarantees must be provided in order to ensure quality control. However, just a few examples of evaluations are seen in the documents and based on this research one can be suspicious of an existing gap between aims and intentions from local councils and what visitors' experience. 


\section{Appendix}

Chart 1. Local councils' pages and documents in the field of leisure and culture.

Local Councils and type of material

\section{Boden}

Bodens kommun, (www.Boden.se). On line (2007-08-28).

Bodens kommun, (www.Boden.se) . Notes from the Youth assembly from 2006-11-29. On

line (2008-12-14).

\section{Örebro}

Örebro kommun. (www.Orebro.se). On line (2007-08-21).

Program for developing democracy and culture political program for Örebro local council (2006). (http://www.orebro.se/politikochdemokrati/styrdokumentpolitiskaprogram/programoc...). (1).

Political aims from the leisure and tourism board. (2007).

(http://www.orebro.e/politikoch demokrati/namnder/fritisochturistnamnden.437c0d5...) (2).

Political aims from the culture- and citizens board (2007) and the board for functional limitations

(http://www.orebro.e/politikoch demokrati/namnder/kulturochmedborgarnamnden4.3...) and (http://www.orebro.e/politikoch demokrati/namndernamndenforfunktionshindrade.4...) (3).

Brickebacken. (www.foreningen-tradet.se). On line (2007-11-14).

Wasagården. (http://www2.orebro.se/fritidsgard/wasagarden/index.php?id=info.htm).

On line (2007-08-20).

\section{Sundsvall}

Sundsvall kommun. (www.Sundsvall.se). On line 2007-08-23/24).

Children's Sundsvall, a guide book to leisure activities 2007.

(http://www.sundsvall.se/badidrottochfritid/fritidsevenemang/barnenssundsvall.4.627988f410febca17f68000131518.html.). (1).

Political program for sports and leisure (2004).

(http://www.sundsvall.se/div/sok.4.19f9c7a107dc1557c5800057824.html?query=m\%C3\%A51+fritid+2004). (2).

Culture politics in Sundsvall (2004).

(http://www.sundsvall.se/div/sok.4.19f9c7a107dc1557c5800057824.html?query=kulturpolitiskt+program+2004). (3).

Aims from the board of leisure and culture (2004).

(http://www.sundsvall.se/demokratiochpolitiker/namnderochkommunledning/namnderochpolitiker/kulturochfritidsnamnd.4.19f 9c7a107dc1557c5800015396.html). (4).

Aims from the board of leisure and culture (2007).

(http://www.sundsvall.se/omsundsvallskommun/organisation/forvaltningar/kulturfritid/styrandedokument.4.3b6cd44910b19752 9fd80005841.html). (4).

Ungpott.(www.unigisundsvall.se/ungpott.htm). On line (2008-12-22).

\section{Munkfors}

Munkfors kommun. (www.Munkfors.se). On line (2007-08-28).

\section{Uppsala}

Uppsala kommun. (www.Uppsala.se). On line 2007-09-12).

The city councils program and the United Nations convention. (1999).

(www.uppsala.se). (1).

A Leisure political program for Uppsala local council. (2006).

(http://www.uppsala.se/Upload/Dokumentarkiv/Externt/Dokument/Om_kommunen/fritidspolitiskt_program.pdf). (2). 
Aims from the children and youth board for open leisure activities for youth clubs. (2006). (http://www.uppsala.se/Omkommunen/Politik--namnder/Namnder/Barn--och-ungdomsnamnden/) (3).

A Culture political program for Uppsala local council (2005).

(http://www.uppsala.se/Upload/Dokumentarkiv/Externt/Dokument/Fritid_o_kultur/kpp.pdf). (4).

Political program the against of use drugs.

(http://www.uppsala.se/Upload/Dokumentarkiv/Externt/Dokument/Om_kommunen/drogpolitisk_policy.pdf). (5).

Aims from the leisure- and natural board. (2007, 2006). (http://www.uppsala.se/Omkommunen/Politik-namnder/Namnder/Fritids--och-naturvardsnamnden/). (6).

Aims from the social board for children and young.

(2007, 2008).

(http://www.uppsala.se/Omkommunen/Politik--namnder/Namnder/Barn--och-ungdomsnamnden/). (7).

A guide for accessibility to culture, leisure and sports in Uppsala.(2007.)

\section{Haninge}

Haninge kommun. (www.Haninge.se). On line (2007-09-10).

Aims and budget for 2007-2009 from the board of culture and leisure. (2006). http://www.haninge.se/OmHaninge/Sok/?quicksearchquery $=\mathrm{m} \% \mathrm{c} 3 \% \mathrm{a} 51+\mathrm{och}+$ budget $+2007-2008$ (1).

Aims and budget for 2007-2009 from the board of culture and leisure. (2007).

http://www.haninge.se/Om-Haninge/Sok/Post.aspx?quicksearchquery=m\%25C3\%25A51\%2520och\%2520budget $\% 25202007$ 2008. (1).

Political program for sports. (2000).

(http://www.haninge.se/Fritid--Idrott/Fritidsgardar/). (2).

No Remorse. (http://unighaninge.se/content/blogsection/9/22/). On line (2007-09-10).

\section{Motala}

Motala kommun. (www.Motala.se). On line (2007-08-28).

Aims from the board of education considering leisure and culture. (2007). (http://www.motala.se/templates/MotIntra_Simplelist 1543.aspx). (1).

What is democracy. (2008).

(http://www.motala.se/templates/MotIntra_SimpleList__2898.aspx). (2).

The educational board's direction- and result aims. (2008).

(http:/www.motala.se/upload/Dokument/BlanketterDokument/Dokument/SkolaUtbildning/

N_Inriktningsochresultatml.pdf).(3).

\section{Linköping}

Linköping kommun. (www.Linkoping.se). On line (2007-08-31).

Political aims from the culture- and leisure board (2007).

(http://www.linkoping.se/kwebNET/Templates/Standard_Print.aspx?NRMODE=Publ...). (1).A report for quality accounting in Linköping (2007). (http://www.linkoping.se/PageFiles/952/2007_2008.doc). (2).

Hangaren Hot Sport Center. (http://www.linkoping.se/kwebNET/Templates/Standard_Print.aspx?NRMODE=Publ..). On line (2007-08-29).

\section{City of Gothenburg}

Göteborgs kommun. (www.Goteborg.se) On line (2008-08-05).

Aims and budget for 2007 and plans for 2008-2009 for leisure and culture. (Suggestions). $\mathrm{http}: / /$ www.goteborg.se/wps/portal/PoliticalSearch?num $=10 \& 1 \mathrm{r}=\&$ as_filetype $=\&$ as_occt $=\&$ as_sitesearch $=\& a$ as_dt $=\& \mathrm{q}=\mathrm{f} \% \mathrm{C} 3 \%$ B6rslag $+\mathrm{m} \% \mathrm{C} 3 \% \mathrm{~A} 51+\% 26+$ inriktning $\% 2$ Fbudget $+2007 \&$ collection $\% 5 \mathrm{~B} \% 5 \mathrm{D}=$ politik_collection $\% 3 \mathrm{AN} \% \mathrm{C} 3 \% \mathrm{~A} 4 \mathrm{mndhandlin}$ gar\&origin_url=\&origin_url_text=.(1).

Meeths. http:/www.centrum.goteborg.se/prod/Centrum/sdfsida/dalis2.nsf/vyPublicerade/EFE... On line (2008-12-22). 


\section{Lund}

Lunds kommun. (www.Lund.se). On line (2007-08-22).

Program for sports activities. (2004). http://www.Lund.se. (1).

Strategically document open leisure activities in Lund. (http://www.lund.se/templates/IFrame2___ 21875.aspx?search=\%c3\%b6ppen\%20fritidsverksamhet\%20i\%20Lund\%20med\%2 0sikte $\% 20 \mathrm{p} \% \mathrm{c} 3 \% \mathrm{a} 5 \% 20$ framtiden). (2).

Political strategy for youth in Lund local council (2006). http://www.Lund.se. (3).

Report pedagogies and leisure 2004-2006.

(http://www.pedagogik.info/DesktopDefault.aspx). (4).

Aims from the culture- and leisure board (2006). (http://www.lund.se/templates/Page__26211.aspx). (5).

Wickmanska. (http://www.lund.se/templates/Page 100051.aspx)

\section{CONFLICT OF INTEREST}

None declared.

\section{ACKNOWLEDGEMENT}

None declared.

\section{REFERENCES}

[1] Harris A, Wyn J, Younes S. Young people and citizenship. Youth Studies Australia 2007; 26(3): 17-27.

[2] Marshall TH. Citizenship and social class. Cambridge 1950; 11 : 28-9.

[3] Hemingway J. Leisure, social capital, and democratic citizenship. J Leis Res 1999; 31(2): 150-65.

[4] Peterson O, Hermansson J, Micheletti M, Teorell J, Westholm A. Demokrati och medborgarskap. Demokratirådets rapport 1998 [Democracy and citizenship. Report from the democratic assembly 1998]. Stockholm: SNS förlag; 1998.

[5] James A, Prout A. Constructing and reconstructing childhood : contemporary issues in the sociological study of childhood. London: Falmer 1997.

[6] Such E, Walker R. Being responsible and responsible beings: children's understanding of responsibility. Children \& society 2004; 18(3): 231-42.

[7] James A, Jenks C, Prout A. Theorizing childhood. Cambridge: Polity Press 1998.

[8] Bennett WL. Civic learning in changing democracies: Challenges for citizenship and civic education. Young citizens and new media London, UK: Routledge 2007.

[9] Arnot M. Freedom's children: A gender perspective on the education of the learner-citizen. Int Rev Educ 2007; 52(1): 67-87.

[10] Beck U, Beck-Gernsheim E. Individualization: Institutionalized individualism and its social and political consequences: Sage Publications Ltd. 2002.

[11] Print M. Citizenship education and youth participation in democracy. Br J Educ Stud 2007; 55(3): 325-45.

[12] Osler A, Starkey H. Education for democratic citizenship: a review of research, policy and practice 1995-2005 1. Res Papers Educ 2006; 21(4): 433-66.

[13] O'Toole MT. Explaining Young People's non-participation: Towards a fuller understanding of the political. Consort Polit Res Jt Sess Workshop 2004. (unpublished).

[14] Bang H. A new ruler meeting a new citizen: culture governance and everyday making: Manchester University Press, Manchester 2003.

[15] Bang H. Among everyday makers and expert citizens. Remaking governance: peoples, politics and the public sphere 2005: 159-78.

[16] O'Toole T, Marsh D, Jones S. Political literacy cuts both ways: The politics of non participation among young people. Polit Q 2003; 74(3): 349-60.
Helve H. Reflexivity and changes in attitudes and value structures. In: Helve $\mathrm{H}$, Wallace $\mathrm{C}$, Eds. Youth, citizenship and empowerment. Aldershot: Ashgate; 2001.

Hoikkala T. The diversity of youth citizenships in the European Union. Young 2009; 17(1): 5.

[19] Sörbom A. Vem är du?: en som spelar med eller en som tittar på? om politiskt engagemang i olika generationer och klasser.[Who are you? One who participates with or one who just watches? About political engagement in different generations and classes]. Stockholms Universitet, Sociologiska institutionen 2000.

[20] Sörbom A. Vart tar politiken vägen?: om individualisering, reflexivitet och görbarhet i det politiska engagemanget [Where did politics go? About individualization, reflexivity and the possiblities to influence the degree of poltical engagement]: Almqvist \& Wiksell International 2002.

[21] Sörbom A. Den goda viljan : en studie av ungdomspolitik i nio kommuner [The good will. A study of youth politics in nine local councils]. Stockholm: Ungdomsstyrelsen 2003.

[22] Tebelius U, Ericsson M. Demokrati som procedur eller engagemang: Unga kvinnors och mäns möjlighet till demokratisk påverkan [Democracy as a procedure or a commitment. Young females and males possibilities to democratic influences]: Högskolan i Halmstad 2001.

[23] Smith N, Lister R, Middleton S, Cox L. Young people as real citizens: Towards an inclusionary understanding of citizenship the paper is based on the project 'negotiating transitions to citizenship'(1134 25 1039), funded by the economic and social research council as part of the 'youth, citizenship and social change'programme. J Youth Stud 2005; 8(4): 425-43.

[24] Tebelius U. How to get youth engaged in democracy. Some experiences from leisure youth work in Sweden. 2004; pp. 11-4.

[25] Mossberger K, Tolbert CJ, Stansbury M. Virtual inequality : beyond the digital divide. Washington, DC: Georgetown University Press 2003.

[26] Norris P. Critical citizens : global support for democratic government. Oxford: Oxford University Press 1999.

[27] Hague BN, Loader BD. Digital democracy: discourse and decision making in the information age. London: Routledge 1999.

[28] Grossman L. The electronic commonwealth. New York: Penguin; 1995.

[29] Alvarez R, Nagler J. The likely consequences of Internet voting for political representation. Loyola Los Angeles Law Rev 2002; 34(3): 1115-53.

[30] Wilhelm AG. Democracy in the digital age: Challenges to political life in cyberspace: Psychology Press 2000.

[31] Margolis M, Resnick D. Politics as usual: Sage Publications, Inc. 2000.

[32] Gallagher R, Hafner C. Democracy, Income and Environmental Quality, Political Economy Research Institute (PERI) Working Paper no. 164, 2008.

[33] Jørgensen M, Phillips LJ. Discourse analysis as theory and method: Sage Publications Ltd 2002.

[34] Börjesson M, Palmblad E. Diskursanalys i praktiken [Discourse analysis in pratice]. Malmö: Liber 2007.

[35] McKee A. Textual analysis: A beginner's guide: Sage Publications Ltd 2003. 
[36] Bruhn Jensen K. Discourses of interviewing: Validating qualitative research findings through textual analysis. In: Kvale S, editor. Issues of validity in qualitative research. Lund: Studentlitteratur; 1989.

[37] Kohlbacher F. The Use of Qualitative Content Analysis in Case Study Research. Forum Qualitative Sozialforschung / Forum: Qualitative Social Research; Vol 7, No 1 (2006): Learning About Risk 2006.

[38] Mayring P, Brunner E. Qualitative inhaltsanalyse. Qualitative Marktforschung 2009:669-80.

[39] Lund kommun. Lund kommun [Lund local council]. [Online] 2007 [cited 2007 August 22]; Available from: www.lund.se

[40] Riksdagen. Socialtjänstlag SFS 2001:453 [Social Services Act SFS 2001:453]. [Online] 2001 [cited; Available from: http://www.notisum.se

[41] Riksdagen. Plan- och bygglag SFS 1987:10 [Planning and building law SFS 1987:10]. [Online] 1987 [cited 2007 December 13]; Available from: http/www.notisum.se

[42] Riksdagen. Lag 1993:387 om stöd och service till vissa funktionshindrade [Law 1993:387 about support and service to citizens with functional limitations]. [Online] 1993 [cited 2007 October 5]; Available from: http://notisum.se

[43] Sundsvall kommun. Sundsvall kommun [Sundsvall local council]. [Online] 2007 [cited 2007 August 23]; Available from: www.sundsvall.se
[44] Linköping kommun. Linköping kommun [Linköping local council]. [Online] 2007 [cited 2007 August 31]; Available from: www.linkoping.se

[45] Brickebacken fritidsgård. Brickebacken fritidsgård [Brickebacken Youth Club]. [Online] 2007 [cited 2007 November 14]; Available from: www.foreningen-tradet.se

[46] Haninge kommun. Haninge kommun [Haninge Local council]. [Online] 2007 [cited 2007 September 10]; Available from: www.haninge.se

[47] Uppsala kommun. Uppsala kommun [Uppsala local council]. [Online] 2007 [cited 2007 September 12]; Available from: www.uppsala.se

[48] Göteborg kommun. Göteborg kommun [Göteborg local council]. [Online] 2008 [cited 2008 August 5]; Available from: www.goteborg.se

[49] Motala kommun. Motala kommun [Motala local council]. [Online] 2007 [cited 2007 August 28]; Available from: www.motala.se

[50] Munkfors kommun. Munkfors kommun [Munkfors local council]. [Online] 2007 [cited 2007 August 28]; Available from: www.munkfors.se

[51] Boden kommun. Boden kommun [Boden local council]. [Online] 2007 [cited 2007 August 28]; Available from: www.boden.se

[52] Sundsvall kommun. Ung Pott. Ung i Sundsvall [Youth money, young in Sundsvall]. [Online] 2008 [cited 2008 December 22]; Available from: www.ungisundsvall.se

[53] Örebro kommun. Örebro kommun [Örebro local council]. [Online] 2007 [cited 2007 August 21]; Available from: www.orebro.se

(C) Lisbeth Lindström; Licensee Bentham Open

This is an open access article licensed under the terms of the Creative Commons Attribution Non-Commercial License (http: //creativecommons.org/licenses/by$\mathrm{nc} / 3.0 /$ ), which permits unrestricted, non-commercial use, distribution and reproduction in any medium, provided the work is properly cited. 